\title{
Influence of Plantain and Sprouted Soybean Pastes on the Nutrient and Proximate Composition of Two Species of Cocoyam Puddings as a Complementary Food
}

\author{
Innocent N. Okwunodulu ${ }^{1, a^{*}}$, Daniel M. Uluocha ${ }^{1, b}$, \\ Felicia U. Okwunodulu ${ }^{2, c}$ \\ 1Department of Food Science and Technology Michael Okpara University of Agriculture, \\ Abia State Nigeria
${ }^{2}$ Chemistry Department Michael Okpara University of Agriculture Umudike, Abia State Nigeria \\ ”anncntokwu@yahoo.com, buluochadaniel@gmail.com, cokwunodulufelicia@gmail.com
}

Keywords: Cocoyam puddings, Nutrient profiles, cocoyam variety, complementary feeding.

\begin{abstract}
Nutrients and proximate composition of the puddings prepared from ede-ocha (Xanthosoma sagittifolium) and ede-cocoindia (Colocasia esculenta) pastes were evaluated. Paste from each cocoyam variety was separately blended with firm ripe plantain, sprouted soybean pastes in the ratio of $100 \%$ cocoyam, $90 \%$ cocoyam: $10 \%$ soybean, $25 \%$ cocoyam: $65 \%$ plantain: $10 \%$ soybean, and $45 \%$ cocoyam: $45 \%$ plantain: $10 \%$ soybean and mixed with equal quantities of seasonings. The formulated blends were wrapped in plantain leaves and boiled for 30 minutes. Values obtained showed that pudding from ede-ocha had a higher moisture content $(56.25 \%)$, protein (4.47\%), fat (1.84\%), ash $(2.57 \%)$, crude fiber $(2.46 \%)$, iron $(0.58 \mathrm{mg})$, and calcium $(5.12 \mathrm{mg})$ than ede-cocoondia, which had 5.52\%, 4.29\%, 1.49\%, 2.45\%, 2.11\%, 0.36\% and 5.01\% respectively. Also, puddings from ede-cocoindia had higher carbohydrate $(39.28 \%)$, vitamin A precursor $(62.90 \mu \mathrm{g})$, vitamin $\mathrm{C}(33.05 \mathrm{mg})$ and zinc $(0.35 \mathrm{mg})$ than that from ede-ocha which had $35.46 \%$, $60.80 \mu \mathrm{g}, 20.50 \mathrm{mg}$, and $0.32 \mathrm{mg}$ respectively. The ede-ocha, therefore, made a better nutritious pudding than ede-cocoindia.
\end{abstract}

\section{Introduction}

Complementary foods $(\mathrm{CF})$ are non breast milk or proven nutritional companion prepared from family meals or specially prepared meal. They are introduced to the diet of breast feeding infants and young children as from six months to two years or more [1]. The CF may be solids, semi-solids or liquids $[1,2]$. Due to high cost of nutritious proprietary foods which are beyond the reach of most nursing mothers in developing countries like Nigeria, CFs formulation from local staples had proved a better option $[3,4]$.

Puddings are popular Nigeria steamed paste prepared from mixture of wet milled root or tuber crops with seasonings such as salt, pepper, crayfish, salt, palm oil and many others, wrapped and steamed in banana leaves and the likes. Water gives soft and smooth consistency to the pudding, crayfish gives protein [5], onions provide flavor, calcium, proteins and iron. Salt supplies sodium chloride, plantain leaves imparts desirable flavour while palm oil adds colour, carotene, energy and fat. Puddings are eaten by adults and infants as complementary or weaning food.

Both cocoyam varieties are tropical root vegetables grown for their edible starchy corms whose potential nutritional components have been reported [7]. They are under-utilized, mainly eating or as soup thickener after boiling [6]. Extreme small sizes of cocoyam starch granules make it easily digestible and suitable for complementary food formulation [3, 7]. Cocoyam corms contain substantial amounts of protein, vitamin $\mathrm{C}$, thiamin, riboflavin, niacin and significant amounts of dietary fiber [8]. Cocoyam has protein content of $5.87 \%$, carbohydrate content of $88.46 \%$ on fresh weight basis [9]. Nutritionally, the cormels of ede-ocha (tannia) are slightly superior to ede-cocoindia (taro) in energy and proteins; but lower in calcium, magnesium, zinc, and trypsin [10]. Both species are valuable sources of the micro-nutrients needed to overcome 'hidden hunger' [11]. The nutritional 
importance of cocoyam depends on the presence of anti-nutritional factors like oxalates [12] and phytates whose higher concentration affects their utilization [7, 10] as they prevent digestion and absorption of essential nutrients [13]. Peeling, grating, soaking, fermentation [14], and prolong (30min) cooking [10] remove cocoyam anti-nutrients [15]. Vitamins are susceptible to both processes while minerals are affected only by leaching. Free amino acids could also be leached or may react with sugars to form protein-oxalate complexes. Starches may be hydrolyzed to sugars. The percentage loss would depend partly on various factors such as the cooking temperatures and on the method of processing [16].

Plantain (Musa paradisiaca) is a starchy staple crop with high carbohydrate content (31 g/100g), low fat content $(0.4 \mathrm{~g} / 100 \mathrm{~g})$ and a good source of energy [17]. Plantain is also good source of vitamins and minerals [18], particularly iron $(24 \mathrm{mg} / \mathrm{kg})$, potassium $(9.5 \mathrm{mg} / \mathrm{kg})$ and calcium $(715 \mathrm{mg} / \mathrm{kg})$. Plantain also contains vitamin A precursor, ascorbic acid, thiamin, riboflavin, niacin and dietary fiber. Nutritional composition of plantain varies with variety, maturity, soil type and degree of ripeness [19]. Ripe plantain had been reported to have more minerals which are freed during ripening for more availability than in unripe plantain [20]. Plantain is also a good source of antioxidants, flavonoids, insignificant levels of toxic compounds [21] and trace amount of serotonin that dilates the arteries to improve blood circulation. Regular consumption helps to cure anemia and maintain a healthy heart [22]. Plantain is used as foods, breakfast cereals, and baby complementary foods [23].

Soybean which belongs to the family leguminosae is a cheap source of good quality protein because of its good balance of the essential amino acids [24], and high quality oil. Soybean contains vitamins, minerals and some anti-nutrients such as phytates, trypsin inhibitors and haemagglutinins most of which can be destroyed during processing. Absence of cholesterol, lactose and presence of essential amino acids makes soybean vital for infant growth and maintenance [25]. Soybean had been reported to contain $43 \%$ of protein, $19.5 \%$ of fat, $21 \%$ of carbohydrates and provides $432 \mathrm{kcal}$ per $100 \mathrm{~g}$ [25]. Soybean is use in production of soy flour, baby foods and others for meeting proteinenergy requirement [26].

Sprouting is an age long act of improving the nutritive value of legumes during which there is reduction in anti-nutrients and flatulence causing oligosaccharides (stachyose and raffinose), thereby increasing protein digestibility and sensory properties [25]. Also, sprouting increases vitamins, mineral (calcium, copper, manganese, and zinc) nutrient bioavailability [27] and free amino acid [28]. Sprouted soybean had been used to formulate complementary foods [4, 29]. Other uses of soybean such baking of cake have been reported [30]. This study aims at comparing the nutritional and proximate values of puddings from ede-ocha and ede-cocoindia

\section{Materials and Methods}

Both ede ocha (Xanthosoma sagittifolium) and ede cocoindia (Colocasia esculenta) cocoyam varieties used in this study were procured from the cocoyam programme of the National Root Crops Research Institute Umudike. Soybean (Glycine max), firm ripe plantain (Musa paradisiaca) and seasonings such peper, cray fish and salt were purchased from Urbani main market in Umuahia, both in Abia State, Nigeria.

\section{Production of soybeans paste}

The method described by Okwunodulu and Okwunodulu [4] used for production of soymilk from sprouted soybean was adopted for production of sprouted soybean paste as shown in Fig. 1.

\section{Production of cocoyam paste}

Cocoyam roots were sorted, cleaned, peeled, washed to remove impurities and milled without adding water to obtain cocoyam paste (Fig. 1). 


\section{Production of plantain paste}

Firm ripe plantain fingers were sorted, cleaned, peeled, washed and milled directly with water addition to obtaining plantain paste (Fig. 1).

\section{Production of complementary pudding}

Eight samples of complementary puddings were formulated. Each sample was formulated as indicated in Table 1 following the procedure in Fig. 1. Samples 101 to 104 were prepared with edeoch $a$ wet paste while samples 105 to 108 with ede-cocoindia wet paste. Same ingredients are added to each formulation. Only the proportions of cocoyam, plantain and soybean pastes were varied within the $600 \mathrm{~g}$ stated in Table 1 . Samples $101-100 \%$ cocoyam, $102-90 \%$ cocoyam, $10 \%$ soybean, 103 $25 \%$ cocoyam, $65 \%$ plantain, $10 \%$ soybean, 104 - $45 \%$ cocoyam, $45 \%$ plantain, $10 \%$ soybean, 105 $100 \%$ cocoyam, 106 - $90 \%$ cocoyam, $10 \%$ soybean, $107-25 \%$ cocoyam, $65 \%$ plantain, $10 \%$ soybean, $108-45 \%$ cocoyam, $45 \%$ plantain, $10 \%$ soybean.

Table 1. Recipe for pudding production

\begin{tabular}{|l|l|}
\hline Ingredients & Quantity \\
\hline Cocoyam, plantain and soybean Paste & $600 \mathrm{~g}$ \\
\hline Onion & $25 \mathrm{~g}$ \\
\hline Water & $150 \mathrm{ml}$ \\
\hline Palm oil & $120 \mathrm{ml}$ \\
\hline Crayfish & $120 \mathrm{~g}$ \\
\hline Salt & $1.5 \mathrm{~g}$ \\
\hline
\end{tabular}




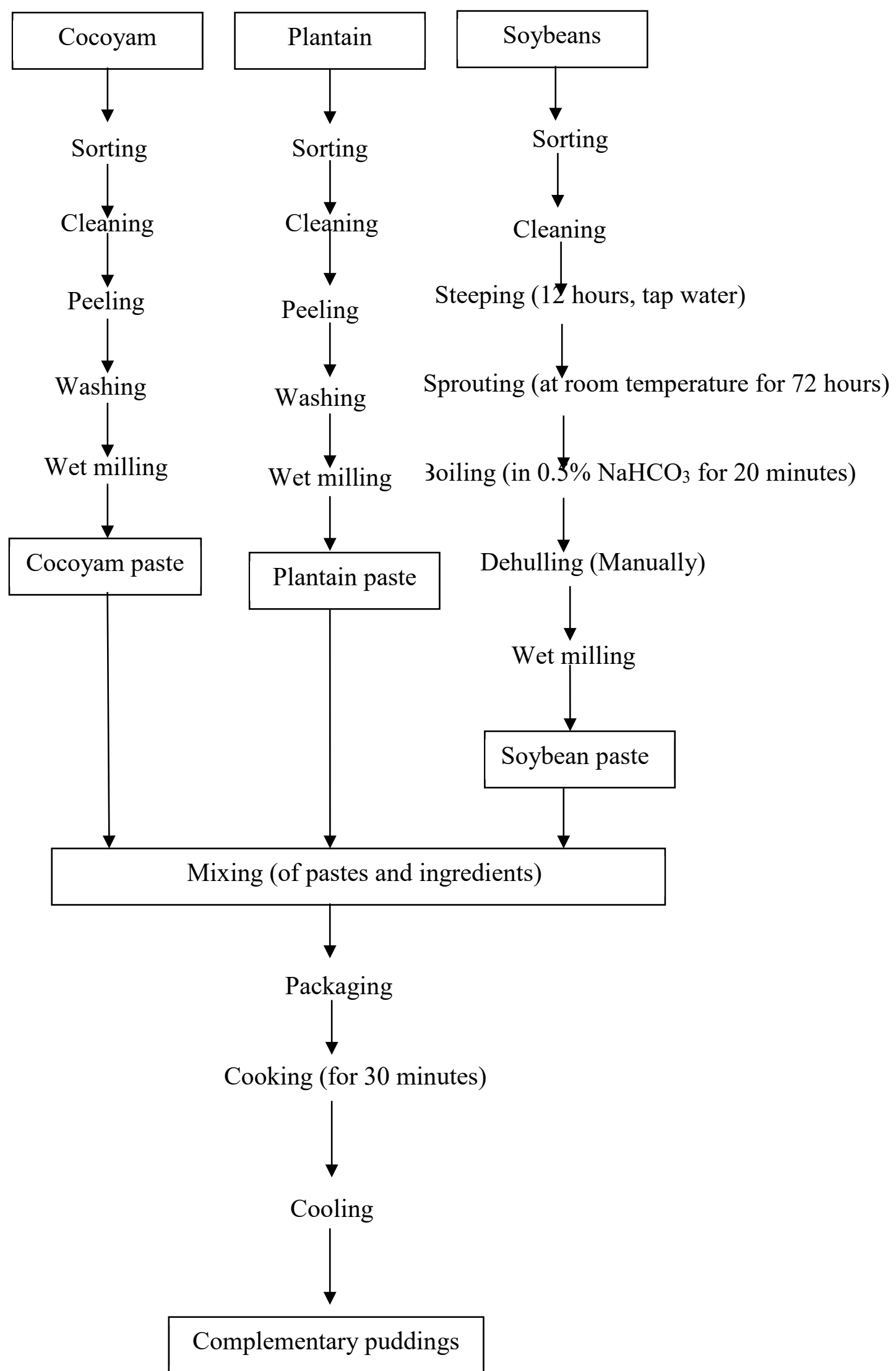

Figure 1. Production flow chart for ede-ocha and ede-ccocoindia pudding production 


\section{Analysis}

All the pudding samples were subjected to nutrient and proximate analyses separately in triplicates as described below. The mean of the triplicate values were used for statistical analyses. Carbohydrate was calculated as difference (100\% - values of all components).

\section{Moisture content determination}

Gravimetric Oven Drying Method protocol described by Onwuka [31] was used. Ten grams $(10 \mathrm{~g})$ of the sample was put into a previously cleaned and weighed moisture can, dried in the oven at $105^{\circ} \mathrm{C}$ for 3 hours, cooled in a desiccator and weighed after. The process was repeated at an hour interval until a constant weight was obtained. The final dry weight was recorded and used to calculate the percentage moisture content of the sample as shown below:

$$
\% \text { Moisture content }=\frac{W_{2-W_{3}}}{W_{2-W_{1}}} \times \frac{100}{1},
$$

where $\mathrm{W}_{1}$ = initial weight of empty can, $\mathrm{W}_{2}=$ weight of can + sample before drying, $\mathrm{W}_{3}=$ weight of can + sample after drying.

\section{Crude protein determination}

Kjeldahl Method of Onwuka [31] was used. One gram (1.0g) of the sample was mixed with $10 \mathrm{mls}$ of concentrated $\mathrm{H}_{2} \mathrm{SO}_{4}$ in a digestion flask. A tablet of selenium catalyst was added before heating in a fume cupboard until a clear solution was obtained (i.e. the digest) which was diluted to $100 \mathrm{mls}$ in a volumetric flask.

$10 \mathrm{mls}$ of the digest was mixed with equal volume of $45 \% \mathrm{NaOH}$ solution in a kjeldahl distillation apparatus. The mixture was diluted into $10 \mathrm{mls}$ of $4 \%$ buric acid containing 3 drops of mixed indicator (bromoscresssol green/methyl red). A total of $50 \mathrm{mls}$ of distillates was collected and titrated against $0.02 \mathrm{~N}$ EDTA from green to deep red endpoint. The $\mathrm{N}_{2}$ content and hence the protein content was calculated using the formula below:

$$
\begin{gathered}
\% \text { Protein }=\% \mathrm{~N}_{2} \times 6.25 \\
\% \mathrm{~N}_{2}=\frac{100}{W} \times \frac{N \times 14}{1000} \times \frac{V_{t}}{V_{a}} T B K,
\end{gathered}
$$

where $\mathrm{w}=$ weight of sample, $\mathrm{N}=$ normality of titrant $\left(0.02 \mathrm{H}_{2} \mathrm{SO}_{4}\right), \mathrm{Vt}=$ total digest volume $(100 \mathrm{~m} / \mathrm{s})$, $\mathrm{Va}=$ volume of digest analyzed $(10 \mathrm{ml}) . \mathrm{T}=$ titre value of sample and $\mathrm{B}=$ titre value of blank.

\section{Ash content determination}

Muffle furnace ignition method described by Onwuka [31] was used. Three grams (3g) of the sample was measured into washed, dried and weighed porcelain crucible and ignited in the muffle furnace at $550^{\circ} \mathrm{C}$. The sample was allowed to ash to a grayish white ash, brought out from the furnace using a forcep and left in a desiccator to cool. The cool porcelain was weighed and ash content calculated as shown below:

$$
\% \text { Ash }=\frac{W_{3}-W_{1}}{W_{2}-W_{1}} \times \frac{100}{1},
$$

where $\mathrm{W}_{1}=$ weight of empty crucible, $\mathrm{W}_{2}=$ weight of crucible + food before drying and $\mathrm{W}_{3}=$ weight of crucible + ash.

\section{Fat content determination}

Soxhlet ether extraction protocol of Onwuka [31] was employed. Three grams $(3 \mathrm{~g})$ of the sample was weighed into a thimble and placed into a reflux flask fitted to a weighed $300 \mathrm{ml}$ round bottom flask. A $300 \mathrm{ml}$ round bottom flask was filled with $250 \mathrm{ml}$ of petroleum ether $\left(\mathrm{Bp} 40\right.$ to $\left.60^{\circ} \mathrm{C}\right)$ and placed on a heating mantle preset at $60^{\circ} \mathrm{C}$ to reflux for about $6 \mathrm{~h}$ during which the vapour rises and leaches all the oil from the sample in the thimble into the round flask. Thereafter, the thimble containing the sample was removed from the reflux flask and the excess was either recovered by 
heating leaving only the oil in the round bottom flask. The flask was detached from the set up and placed on the oven set at $105^{\circ} \mathrm{C}$ to dry off excess ether, allowed to cool in a desiccator and then reweighed and the oil was calculated as shown below:

$$
\% \text { Fat }=\frac{\text { Weight of fat }}{\text { Weight of sample }} \times \frac{100}{1} \%
$$

\section{Crude fiber determination}

The method of Onwuka [31] was used. Two (2g) grams of each sample were digested with 200 $\mathrm{ml}$ of $1.25 \% \mathrm{H}_{2} \mathrm{SO}_{4}$ solution under reflux for $30 \mathrm{~min}$ boiling. The digest was allowed to cool and then filtered with Buckner funnel equipped with muslin cloth. The residue was washed thrice with hot water, scooped into a conical flask and digested with $200 \mathrm{ml}$ of $1.25 \% \mathrm{NaOH}$ solution under reflux for 30 min boiling. The digest was cooled, filtered and washed thrice with distilled water. The residue was drained and scooped into a previously dried and weighed crucible and then put into the oven to dry at $105^{\circ} \mathrm{C}$ to a constant mass. The dish with its content was reweighed after drying and then placed in the muffle furnace to ash at temperature of $550^{\circ} \mathrm{C}$ for $3 \mathrm{~h}$. The ash was withdrawn at the end and put in a bell jar and reweighed. The weight of fiber was calculated as a percentage of weight of sample analyzed as below:

$$
\% \text { Crude fiber }=\frac{\mathrm{W}_{2}-\mathrm{W}_{3}}{\text { Weight of sample }} \times \frac{100}{1} \%
$$

where $\mathrm{W}_{2}=$ weight of crucible + sample after boiling, washing and drying and $\mathrm{W}_{3}=$ weight of crucible + sample as ash.

\section{Calcium determination}

The EDTA complexometric titration method described by James [32] was used. 10g of the sample was dispensed into separate conical flasks, pinches of the masking agents (potassium cyanide, potassium ferrocyanide and hydroxyl hydrochloride) were measured into each flask and $20 \mathrm{ml}$ of ammonia buffer was added to raise the $\mathrm{pH}$. The flask containing sample at $10.0 \mathrm{pH}$ a pinch of Erichrome dark black indicator was added and titrated against 0.02N EDTA solution while Solochrome dark blue indicator was added and titrated against $0.02 \mathrm{~N}$ EDTA solution at $\mathrm{pH}$ of 12.0. A reagent blank was titrated as a control. The calcium content of the samples was calculated using the standard that $1 \mathrm{ml}$ of $1 \mathrm{~N}$ EDTA has an equivalence of $20.04 \mathrm{mg}$ calcium.

$$
\% \text { calcium }=(100 / \mathrm{W} \times \mathrm{N} / 100 \times \mathrm{Vf} / \mathrm{Va}) \text {, }
$$

where $\mathrm{W}=$ Weight of sample analyzed, $\mathrm{Vf}=$ Volume of extract, $\mathrm{Va}=$ Volume of extract used and $\mathrm{N}$ $=$ Normality.

\section{Zinc determination}

Zinc was determined according to AOAC [33] method. One gram (1g) of the sample was first digested with $20 \mathrm{ml}$ of acid mixture $\left(650 \mathrm{ml}\right.$ concentrated $\mathrm{HNO}_{3}, 80 \mathrm{ml}$ perchloric acid (PCA). About $5 \mathrm{ml}$ of the digest was diluted to $100 \mathrm{ml}$ with distilled water and subjected to AAS reading. Also a standard solution of various zinc concentrations of $0.0,0.2$ and 1.0 was prepared and subjected to AAS to generate the standard curve. The concentration was calculated by extrapolation on the standard curve.

\section{Determination of iron}

The iron content was determined by spectrophotometric method of James [32]. One gram (1g) of the sample was first digested with $20 \mathrm{ml}$ of acids mixture $\left(650 \mathrm{ml}\right.$ concentrated $\mathrm{HNO}_{3}, 80 \mathrm{ml}$ perchloric acid and $20 \mathrm{ml}$ concentrated $\mathrm{H}_{2} \mathrm{SO}_{4}$ ). The digest was diluted by making up to $100 \mathrm{ml}$ with distilled water. $2 \mathrm{ml}$ of the sample solution was pipette inside a flask before $3 \mathrm{ml}$ buffer solution, $2 \mathrm{ml}$ hydroquine solution and $2 \mathrm{ml}$ bipyridyl solution were added. The absorbance reading was taken at wavelength of $520 \mathrm{~nm}$ and the blank was used to zero the instrument. Also, a standard solution of iron 
was prepared by dissolving $3.512 \mathrm{~g}$ of $\mathrm{Fe}\left(\mathrm{NH}_{4}\right)_{2} .\left(\mathrm{SO}_{4}\right) .6 \mathrm{H}_{2} \mathrm{O}$ in water and two drop of $0.5 \mathrm{~N} \mathrm{HCL}$ was added and diluted to $500 \mathrm{ml}$ with distilled water. The iron standard was further prepared at different concentration at $2 \mathrm{ppm}$ to $10 \mathrm{ppm}$ by diluting with distilled water. $3 \mathrm{ml}$ buffer solution, $2 \mathrm{ml}$ hydroquinone solution and $2 \mathrm{ml}$ bipyridtyl solution were added. Absorbance reading was taken at $520 \mathrm{~nm}$. The readings were used to plot a standard iron curve for extrapolation.

\section{Vitamin A determination}

Spectrophotometric method of Okwu and Josiah [34] was employed. Five gram (5g) of sample was dissolved in $30 \mathrm{ml}$ of absolute alcohol (ethanol) and $3 \mathrm{ml}$ of $5 \%$ potassium hydroxide was added. The mixture was boiled under reflux for 30 minutes, cooled rapidly with running water, filtered; $30 \mathrm{ml}$ of distilled water was added and transferred into a separating funnel. The lower layer was discarded and the upper layer was washed with $50 \mathrm{mls}$ of distilled water. The extract was evaporated to dryness and dissolved in 10mls of isoprophyl alcohol and its absorbance was measured at $325 \mathrm{~nm}$ and vitamin A was calculated as.

$$
\text { Vit. A }(\mathrm{mg} / 100 \mathrm{~g})=\frac{100}{w} \times \frac{a u}{a s} \times c,
$$

where $\mathrm{au}=$ absorbance of test sample, as $=$ absorbance of standard solution, $\mathrm{c}=$ concentration of the test sample and $\mathrm{w}=$ weight of sample.

\section{Determination of vitamin $\mathbf{C}$}

The method used was as described by Ukwu and Josiah [34]. 10g of the sample was extracted with 50ml EDTA/TCA extracting solution for 1 hour and filtered through a Whatman filter paper into a $250 \mathrm{ml}$ conical flask, $10 \mathrm{ml}$ of $30 \% \mathrm{KI}$ and $50 \mathrm{mls}$ of distilled water was added. Starch indicator $(2 \mathrm{ml}$ of $1 \%$ ) was added and titrated against $0.01 \mathrm{ml} \mathrm{CuSO}_{4}$ solution to a dark endpoint.

$$
\text { Vit. } \mathrm{C}(\mathrm{mg} / 100 \mathrm{~g})=0.88 \times \frac{100}{5} \times \frac{V_{f}}{20} \times \frac{T}{1}
$$

where $\mathrm{V}_{\mathrm{f}}=$ volume of the extract, $\mathrm{T}=$ Sample titre - blank titer.

\section{Statistical analyses}

Mean data obtained from triplicate analyses were subjected to analysis of variance (ANOVA). A completely randomized design using SPSS version 22 was used to analyze the data. Means were separated using Duncan multiple range test at 95\% confidence level $(\mathrm{p}<0.05)$.

\section{Results and Discussion}

Proximate results of the puddings from both cocoyam varieties were presented in Table 2 . Moisture content $(56.25 \%)$ of ede-ocha pudding in sample 101 (100\% cocoyam) was significantly $(\mathrm{p}<0.05)$ higher than $52.55 \%$ from ede-cocoindia pudding in sample $105(100 \%$ cocoyam $)$. The difference could be due to variety. Same reason may explain higher MC in sample $104(45 \%$ cocoyam, $45 \%$ plantain, $10 \%)$ than 108 (45\% cocoyam, $45 \%$ plantain, $10 \%$ soybean) which were their least $\mathrm{MC}$ values. The puddings $\mathrm{MC}$ from $100 \%$ cocoyam of both varieties were significantly higher than their counterparts with plantain and soybean pastes in their formulations. Protein must have bound with some water [30, 35] resulting lower MC. The more the moisture, the softer the pudding texture. Water also helps to maintain smooth paste consistency [5], lubricates and adds juiciness during eating and swallowing. Therefore, puddings from 100\% ede-ocha will be easier to swallow than that from ede-cocoindia and those with plantain and soybean in their formulation.

Crude protein content of ede-ocha puddings $(4.51 \%)$ in sample $102(90 \%$ cocoyam, 10\% soybean) was significantly $(\mathrm{p}<0.05)$ higher than $4.29 \%$ from ede-cocoindia puddings in sample 106 ( $90 \%$ cocoyam, 10\% soybean). The difference could be due to variety effects as both had same $10 \%$ soybean paste inclusion. Protein content superiority of ede-ocha over ede-cocoindia reported by [10] was substantiated by higher protein content $(3.35 \%)$ of $100 \%$ ede-ocha puddings than $3.22 \%$ from $100 \%$ ede-cocoindia pudding. Inclusion of plantain and soybean in the puddings increased 
significantly their protein contents, but the increase in ede-ocha puddings were more than that in edecocoindia. Despite these, consumption of 300 to $400 \mathrm{~g}$ and 310 to $420 \mathrm{~g}$ of puddings from ede-ocha and ede-cocoyam respectively will meet the recommended protein daily intake of $9.1 \mathrm{~g} / \mathrm{d}$ [36] which is possible considering infants' stomach capacity of $200 \mathrm{ml}$ [37]. Protein is an essential nutrient for proper growth and development of the body of infants and young children and a major structural component of muscle tissues which helps to repair increase and maintain children muscle mass. Besides, protein is also a component of child's blood, organs, skin and glands [38].

There is varietal influence on fat content of the puddings of both cocoyam varieties. This was reflected on significantly $(\mathrm{p}<0.05)$ higher fat content of ede-ocha pudding $(1.84 \%)$ in sample 104 (45\% cocoyam, $45 \%$ plantain, $10 \%$ soybean) than $1.49 \%$ from ede-cocoyam pudding in sample 108 (45\% cocoyam, $45 \%$ plantain, $10 \%$ soybean). The variation may also be attributed to higher $(39.28 \%)$ carbohydrate content of ede-cocoindia than $35.46 \%$ from ede-ocha puddings which may have proportionally reduced the total percent fat content despite higher fat content $(1.21 \%)$ of edecocoindia than ede-ocha $(0.95 \%)$. Besides, all the pudding samples from both varieties with same formulations were significantly difference $(p<0.05)$ from each other. Fat contribution from the puddings of both cocoyam varieties agrees with recommendations of vegetable oil inclusion in infant and children foods [39] to increase the energy density and transport vehicle for fat soluble vitamins. Fat will aid infant in swallowing the puddings while enhancing the flavor for increase acceptability.

Ash, an index of mineral content of the puddings exhibited significant $(\mathrm{p}<0.05)$ variations with cocoyam variety. Maximum ash content $(2.57 \%)$ was from ede-ocha pudding in sample $104(45 \%$ cocoyam, $45 \%$ plantain, $10 \%$ soybean) while the lease value $(2.31 \%)$ was from ede-cocoindia in sample 104 (45\% cocoyam, 45\% plantain, 10\%). Also, significant higher ash content $(2.14 \%)$ of sample 105 containing $100 \%$ ede-cocoindia than $2.01 \%$ in sample 101 with $100 \%$ ede-ocha follow suit and also validated the report of [10] that ede-cocoindia contains more mineral than ede-ocha. It is interesting to note that despite same formulations and higher ash content of ede-cocoindia, ash content of sample 104 (45\% cocoyam, 45\% plantain, 10\% soybean) was higher than sample 108 (45\% cocoyam, $45 \%$ plantain, $10 \%$ soybean). This may mean that vitamin - mineral interactions [29] which are nutrient loss [40], and leaching of mineral [16] may have been higher in ede-cocoindia than in ede-ocha. Ash is an indication of the amount of minerals (trace elements) with a well defined biochemical functions in the human body [41]. Iron works in synergy with protein and copper to produce red blood cells that transport oxygen from lungs to all the tissues for maintaining all body's life functions like fuelling the cell division and growth of a developing body [42]. Iron deficiency leads to anemia which is a preventable disease through food fortification or formulations for infants and young children [43]. Calcium is mainly used for bones, teeth blood clotting, nerve, muscle health, and others $[42,44]$.

Maximum crude fiber content of ede-ocha pudding (2.46\%) in sample 103 (25\% cocoyam, 65\% plantain, $10 \%$ soybean) which was significantly $(\mathrm{p}<0.05)$ higher than $2.10 \%$ from ede-cocoindia pudding in sample 107 (25\% cocoyam, 65\% plantain, 10\% soybean) confirmed the differential varietal effects. Both samples have the same formulations. The value $(2.46 \%)$ from ede-ocha pudding compared better to $2.54 \%$ reported by Olayiwola et al [45] from pudding prepared from cocoyam flour than $2.10 \%$ from ede-cocoindia pudding. The difference could be as a result of lower MC of cocoyam flour which may have increased the ash content by proportion. Consumption of 2 to $3 \mathrm{~g} / \mathrm{d}$ of puddings from both cocoyam varieties will meet fiber RDI of 5g.d [46] for infants aged between 6 months to one year which made them a good fiber source [8]. Crude fiber is a carbohydrate subtype consisting of soluble and insoluble portions responsible for normalizing infant's bowel movement prevents constipation and helps control blood pressure [46].

Significant higher carbohydrate content of ede-cocoindia pudding $(39.28 \%)$ in sample 105 (100\% cocoyam) than ede-ocha $(35.46 \%)$ in sample $104(100 \%$ cocoyam) could be traced to varietal difference. Same reason holds for the significant $(\mathrm{p}<0.05)$ higher carbohydrate content from all edecocoindia puddings than their counterpart from ede-ocha with same formulation. This validated the superiority of ede-cocoindia over ede-ocha reported by Akpan and Umoh [10]. However, consumption of 158 to $330 \mathrm{~g} / \mathrm{d}$ and 175 to $370 \mathrm{~g} / \mathrm{d}$ respectively of puddings from ede-cocoindia and 
ede-ocha will meet the infant's total carbohydrate RDI of 60 to $95 \mathrm{~g} / \mathrm{d}$ per serving for infants aged between 6 to 12 months [36]. These will also meet $130 \mathrm{~g} / \mathrm{d}$ of total carbohydrate daily intake for children beyond 12 months [47]. Lower quantity of ede-cocoindia is required to meet the RDI than ede-ocha. Carbohydrates provide energy needed to fuel children's metabolism, supports growth, keeps their brain and nervous systems working and maintains overall health [47].

Table 2. Proximate composition of puddings prepared from two varieties of cocoyam blended with plantain and soybean [\%]

\begin{tabular}{lllllll}
\hline Samples & MC & Crude protein & Crude fat & Ash & CF & Carbohydrate \\
& & & & & & \\
\hline $\mathbf{1 0 1}$ & $56.25^{\mathrm{a}} \pm 0.21$ & $3.35^{\mathrm{e}} \pm 0.01$ & $0.95^{\mathrm{f}} \pm 0.01$ & $2.01^{\mathrm{f}} \pm 0.01$ & $1.94^{\mathrm{e}} \pm 0.01$ & $35.46^{\mathrm{e}} \pm 0.01$ \\
$\mathbf{1 0 2}$ & $55.05^{\mathrm{b}} \pm 0.07$ & $4.51^{\mathrm{a}} \pm 0.28$ & $1.82^{\mathrm{a}} \pm 0.02$ & $2.32^{\mathrm{d}} \pm 0.10$ & $1.98^{\mathrm{d}} \pm 0.02$ & $34.34^{\mathrm{h}} \pm 0.01$ \\
$\mathbf{1 0 3}$ & $54.40^{\mathrm{c}} \pm 0.14$ & $4.47^{\mathrm{b}} \pm 0.02$ & $1.82^{\mathrm{a}} \pm 0.01$ & $2.37^{\mathrm{c}} \pm 0.01$ & $2.46^{\mathrm{a}} \pm 0.01$ & $34.52^{\mathrm{g}} \pm 0.01$ \\
$\mathbf{1 0 4}$ & $54.05^{\mathrm{c}} \pm 0.07$ & $4.45^{\mathrm{b}} \pm 0.02$ & $1.84^{\mathrm{a}} \pm 0.01$ & $2.57^{\mathrm{a}} \pm 0.03$ & $2.41^{\mathrm{b}} \pm 0.01$ & $34.65^{\mathrm{f}} \pm 0.01$ \\
$\mathbf{1 0 5}$ & $52.55^{\mathrm{d}} \pm 0.35$ & $3.22^{\mathrm{f}} \pm 0.01$ & $1.21^{\mathrm{e}} \pm 0.01$ & $2.14^{\mathrm{e}} \pm 0.01$ & $1.64^{\mathrm{g}} \pm 0.01$ & $39.28^{\mathrm{a}} \pm 0.03$ \\
$\mathbf{1 0 6}$ & $51.15^{\mathrm{f}} \pm 0.07$ & $4.29^{\mathrm{c}} \pm 0.01$ & $1.36^{\mathrm{d}} \pm 0.03$ & $2.45^{\mathrm{b}} \pm 0.01$ & $1.77^{\mathrm{f}} \pm 0.01$ & $38.99^{\mathrm{b}} \pm 0.01$ \\
$\mathbf{1 0 7}$ & $52.10^{\mathrm{d}} \pm 0.28$ & $4.20^{\mathrm{d}} \pm 0.01$ & $1.43^{\mathrm{c}} \pm 0.01$ & $2.35^{\mathrm{c}} \pm 0.01$ & $2.10^{\mathrm{c}} \pm 0.01$ & $37.86^{\mathrm{d}} \pm 0.03$ \\
$\mathbf{1 0 8}$ & $51.90^{\mathrm{e}} \pm 0.14$ & $4.17^{\mathrm{d}} \pm 0.01$ & $1.49^{\mathrm{d}} \pm 0.02$ & $2.31^{\mathrm{d}} \pm 0.01$ & $2.11^{\mathrm{c}} \pm 0.02$ & $38.03^{\mathrm{c}} \pm 0.01$
\end{tabular}

The values are mean triplicate determinations \pm standard deviations. Mean values in same column with different superscripts $(a-f)$ are significantly different $(\mathrm{p}<0.05)$. Values in same column with same superscripts are not significantly $(\mathrm{p}<0.05)$ different. Sample 101-104 are produced from ede-ocha and 105-108 from ede-cocoindia. 101 = 100\% cocoyam, $102=90 \%$ cocoyam, $10 \%$ soybean, $103=25 \%$ cocoyam, $65 \%$ plantain, $10 \%$ soybean, $104=45 \%$ cocoyam, $45 \%$ plantain, $10 \%$ soybean, $105=100 \%$ cocoyam, $106=90 \%$ cocoyam, $10 \%$ soybean, $107=25 \%$ cocoyam, $65 \%$ plantain, $10 \%$ soybean, $108=45 \%$ cocoyam, $45 \%$ plantain, $10 \%$ soybean. $\mathrm{MC}=$ moisture content and $\mathrm{CF}=$ crude fiber

\section{Vitamin composition of the puddings}

Vitamin content results of puddings from both cocoyam varieties were presented in Table 3.Varietal effects increased significantly $(\mathrm{p}<0.05)$ the vitamin A content of the puddings from $60.80 \mu \mathrm{g}$ (ede-ocha puddings) in sample 103 (25\% cocoyam, 65\% plantain, $10 \%$ soybean) to $62.90 \mu \mathrm{g}$ (ede-cocoindia) pudding in sample 107 (25\% cocoyam, 65\% plantain, 10\% soybean). The difference was validated by higher vitamin A content $(13.55 \mu \mathrm{g})$ of $100 \%$ ede-cocoindia than $12.95 \mu \mathrm{g}$ from $100 \%$ ede-ocha puddings despite same formulations. Vitamin A is a vital micronutrient in complementary foods which deficiency is of public health concern worldwide. However, puddings from ede-cocoindia require ingestion of $794 \mathrm{~g}$ which is lower than $822 \mathrm{~g}$ from ede-ocha to meet vitamin A RDI of $500 \mu \mathrm{g} / \mathrm{d}$ [48] for infant and young children aged between 6 months to 2 years.

Varietal difference also manifested in the maximum vitamin $\mathrm{C}$ content of ede-cocoindia (33.05mg) in sample 107 (25\% cocoyam, 65\% plantain, 10\% soybean) which was significantly $(\mathrm{p}<0.05)$ higher than $20.50 \mathrm{mg}$ from ede-ocha pudding in sample 103 (25\% cocoyam, 65\% plantain, $10 \%$ soybean). Also, vitamin C content $(6.32 \mathrm{mg})$ of $100 \%$ ede-cocoindia was significantly $(\mathrm{p}<0.05)$ higher than $4.81 \mathrm{mg}$ from $100 \%$ ede-ocha puddings. Lower vitamin $\mathrm{C}$ values obtained in $100 \%$ cocoyam of both varieties could be attributed to non incorporation of plantain and soybean which may mean that their vitamin $C$ content is low. Plantain is a rich source of vitamin $C[18,19]$. Though puddings from both cocoyam varieties were between 'good' and 'very good' sources of vitamin C [49], but more (195 to $832 \mathrm{~g}$ ) quantities of pudding from ede-ocha is needed to meet vitamin C RDI of 40mg for infants aged between 1 to $3 y \mathrm{ys}$ [50] than 121 to $633 \mathrm{~g}$ from ede-cocoindia puddings. This implies that ede-cocoindia will meet vitamin C RDI easier than ede-ocha puddings and therefore a better source. Besides, as vitamin $\mathrm{C}$ is needed in trace amount for biological functions [32], it implies that cocoyam of both varieties in this study are adequate to meet infants' vitamin C RDI of 40mg. Vitamin $C$ helps in maintaining healthy immune systems, fight infections, synthesis of collagens which gives structure and maintains healthy muscle, vascular tissue, tendons, ligaments, teeth, bones, gum, cartilage, joints, lining, skin and blood vessels [50]. Severe vitamin C deficiency leads to scurvy, a fatal disease [51] which causes malformation of infants' bone [49]. 
Table 3. Vitamin composition of puddings prepared from two varieties of cocoyam blended with plantain and soybean

\begin{tabular}{lll}
\hline Samples & Vitamin A $[\mu \mathrm{g}]$ & Vitamin C $[\mathrm{mg}]$ \\
\hline $\mathbf{1 0 1}$ & $12.95^{\mathrm{g}} \pm 0.07$ & $4.81^{\mathrm{b}} \pm 0.01$ \\
$\mathbf{1 0 2}$ & $22.15^{\mathrm{f}} \pm 0.21$ & $8.70^{\mathrm{b}} \pm 0.00$ \\
$\mathbf{1 0 3}$ & $60.80^{\mathrm{b}} \pm 0.78$ & $20.50^{\mathrm{ab}} \pm 0.14$ \\
$\mathbf{1 0 4}$ & $55.65^{\mathrm{c}} \pm 0.56$ & $18.25^{\mathrm{a}} \pm 0.14$ \\
$\mathbf{1 0 5}$ & $13.55^{\mathrm{g}} \pm 0.07$ & $6.32^{\mathrm{b}} \pm 0.01$ \\
$\mathbf{1 0 6}$ & $26.3^{\mathrm{e}} \pm 0.07$ & $11.10^{\mathrm{b}} \pm 0.14$ \\
$\mathbf{1 0 7}$ & $62.90^{\mathrm{a}} \pm 0.14$ & $33.05^{\mathrm{a}} \pm 0.07$ \\
$\mathbf{1 0 8}$ & $45.35^{\mathrm{d}} \pm 0.07$ & $11.95^{\mathrm{b}} \pm 0.07$
\end{tabular}

Values are mean of triplicate determinations \pm standard deviations. Mean values in same column with different superscript (a-g) are significantly different $(\mathrm{P}<0.05)$. Sample 101-105 are produced from ede-ocha and 105-108 from ede-cocoindia. $101=100 \%$ cocoyam, $102=90 \%$ cocoyam, $10 \%$ soybean, $103=25 \%$ cocoyam, $65 \%$ plantain, $10 \%$ soybean, $104=45 \%$ cocoyam, $45 \%$ plantain, $10 \%$ soybean, $105=100 \%$ cocoyam, $106=90 \%$ cocoyam, $10 \%$ soybean, $107=25 \%$ cocoyam, $65 \%$ plantain, $10 \%$ soybean, $108=45 \%$ cocoyam, $45 \%$ plantain, $10 \%$ soybean.

\section{Mineral composition of puddings}

Table 4 presents the results of the mineral content of the puddings from both cocoyam varieties. The ede-ocha puddings which recorded maximum iron content of $0.58 \mathrm{mg} / 100 \mathrm{~g}$ in sample $103(25 \%$ cocoyam, $65 \%$ plantain, $10 \%$ soybean) was significantly $(\mathrm{p}<0.05)$ higher than $0.56 \mathrm{mg} / 100 \mathrm{~g}$ from ede-cocoindia pudding in sample 107 (25\% cocoyam, 65\% plantain, 10\% soybean). Varietal difference can explain this as $100 \%$ ede-ocha pudding in sample 101 had more iron $(0.45 \mathrm{mg} / 100 \mathrm{~g})$ than $0.40 \mathrm{mg} / \mathrm{g}$ from ede-cocoindia pudding in sample 105 . Besides, both puddings had same formulation. Though puddings from both cocoyam varieties responded linearly to iron increase due to plantain inclusion in their formulations [18], but those from ede-ocha still maintained their significant superiority when compared to their corresponding counterparts. General lower iron content from the puddings of both cocoyam varieties apart from variety may be attributed to leaching during boiling [16] and interaction with calcium and vitamin $C$ in the puddings [29]. Meeting iron RDI of $11 \mathrm{mg} / \mathrm{d}$ [52] for infants aged between 6 months to 2 years requires consumption of higher quantities of the puddings $(>1.896 \mathrm{~kg})$ from both cocoyam varieties which makes the puddings poor sources of iron unless other iron rich food nutrients are used in the formulations. Therefore, the puddings should be taken along with iron rich foods. Iron works in synergy with protein and copper to produce red blood cells that transport oxygen from lungs to all the tissues where they are needed for maintaining all body's life functions like fuelling the cell division and growth of a developing body [42]. Advanced stage of iron depletion leads to anemia which is characterized with fatigue and shortage of blood [53].

Maximum zinc content $(0.35 \mathrm{mg} / 100 \mathrm{~g})$ obtained from ede-cocoindia pudding in sample 107 ( $25 \%$ cocoyam, $65 \%$ plantain, $10 \%$ soybean) was significantly $(\mathrm{p}<0.05)$ higher than $0.32 \mathrm{mg} / 100 \mathrm{~g}$ from ede-ocha pudding in sample 103 (25\% cocoyam, 65\% plantain, 10\% soybean) which may be traced to varietal differences as both puddings have same formulations. This was substantiated by significant $(0<0.05)$ higher zinc content of $100 \%$ ede-cocoindia pudding in sample 105 $(0.29 \mathrm{mg} / 100 \mathrm{~g})$ than $0.28 \mathrm{mg} / 100 \mathrm{~g}$ from ede-ocha pudding. Zinc values obtained from puddings of both cocoyam varieties were lower than $0.44 \mathrm{mg}$ obtained by Olayiwola et al [45] from pudding prepared from cocoyam flour which may be due to drying and cocoyam variety used. Zinc content of all the puddings of both varieties will meet the RDI of $2 \mathrm{mg}$ to $3 \mathrm{mg}$ /day for infants aged between 6 months to 2 years [48] by consuming 625 to $1079 \mathrm{~g}$ for ede-ocha puddings and 571 to $857 \mathrm{~g}$ for edecocoindia puddings. Puddings from ede-cocoindia are therefore better zinc source and can meet the zinc RDI easier than that from ede-ocha. Despite this, both puddings are good zinc source for older children aged $(>1 y)$ than young children as consumption of these quantities per day is feasible. Adequate zinc intake supports protein metabolism, wound healing, growth, immune function and others. In young children zinc deficiency results in retarded growth and learning ability [54]. 
Varietal influence was also noticed in the puddings calcium content. Maximum calcium value $(5.12 \mathrm{mg} / 100 \mathrm{~g})$ from $100 \%$ ede-ocha puddings in sample 101 was significantly $(\mathrm{p}<0.05)$ higher than $5.01 \mathrm{mg} / 100 \mathrm{~g}$ obtained from $100 \%$ ede-cocoindia in sample 105 . This justified the earlier report that plantain [18] and cocoyam [55] are good sources of minerals with ede-ocha being superior [10]. It is worthy to note that despite the difference, puddings from both cocoyam varieties exhibited lower calcium values in those puddings with plantain and soybean pastes inclusions than in their $100 \%$ counterparts. This could be attributed to interactions between protein and calcium content of the formulations [4]. Calcium is of tremendous importance to infants and young children especially in healthy development of their bones and teeth [56]. Due to general low calcium content of the puddings from both cocoyam varieties, consumption of more than $2700 \mathrm{~g}$ will be required to meet calcium RDI of 270 to $600 \mathrm{mg}$ /day [56] for infants aged between 7 to 12 months. This makes the puddings poor calcium sources for young infants, but their $100 \%$ cocoyam puddings were better.

Table 4. Mineral composition of puddings prepared from two varieties of cocoyam blended with plantain and soybean [mg]

\begin{tabular}{llll}
\hline Samples & Iron & Zinc & Calcium \\
\hline $\mathbf{1 0 1}$ & $0.45^{\mathrm{e}} \pm 0.16$ & $0.28^{\mathrm{h}} \pm 0.01$ & $5.12^{\mathrm{a}} \pm 0.00$ \\
$\mathbf{1 0 2}$ & $0.39^{\mathrm{g}} \pm 0.01$ & $0.30^{\mathrm{f}} \pm 0.12$ & $5.00^{\mathrm{c}} \pm 0.01$ \\
$\mathbf{1 0 3}$ & $0.58^{\mathrm{a}} \pm 0.01$ & $0.32^{\mathrm{d}} \pm 0.03$ & $4.11^{\mathrm{g}} \pm 0.00$ \\
$\mathbf{1 0 4}$ & $0.51^{\mathrm{c}} \pm 0.03$ & $0.31^{\mathrm{e}} \pm 0.12$ & $4.40^{\mathrm{e}} \pm 0.21$ \\
$\mathbf{1 0 5}$ & $0.40^{\mathrm{f}} \pm 0.02$ & $0.29^{\mathrm{g}} \pm 0.00$ & $5.01^{\mathrm{b}} \pm 0.02$ \\
$\mathbf{1 0 6}$ & $0.36^{\mathrm{h}} \pm 0.01$ & $0.33^{\mathrm{c}} \pm 0.10$ & $4.70^{\mathrm{d}} \pm 0.01$ \\
$\mathbf{1 0 7}$ & $0.56^{\mathrm{b}} \pm 0.00$ & $0.35^{\mathrm{a}} \pm 0.21$ & $4.00^{\mathrm{h}} \pm 0.01$ \\
$\mathbf{1 0 8}$ & $0.48^{\mathrm{d}} \pm 0.02$ & $0.34^{\mathrm{b}} \pm 0.01$ & $4.32^{\mathrm{f}} \pm 0.14$
\end{tabular}

Values are mean triplicate determinations \pm standard deviations. Mean values in same column with different superscripts $(\mathrm{a}-\mathrm{h})$ are significantly different $(\mathrm{p}<0.05)$. Samples 101-105 are produced from ede-ocha and 105-108 from ede-cocoindia. $101=100 \%$ cocoyam, $102=90 \%$ cocoyam, $10 \%$ soybean, $103=25 \%$ cocoyam, $65 \%$ plantain, $10 \%$ soybean, $104=45 \%$ cocoyam, $45 \%$ plantain, $10 \%$ soybean, $105=100 \%$ cocoyam, $106=90 \%$ cocoyam, $10 \%$ soybean, $107=25 \%$ cocoyam, $65 \%$ plantain, $10 \%$ soybean, $108=45 \%$ cocoyam, $45 \%$ plantain, $10 \%$ soybean

\section{Conclusions}

Variety had significant influence in the nutrient and proximate composition of puddings from ede-ocha and ede-cocoindia. Puddings from ede-ocha variety had higher moisture, protein, fat, ash, fiber, iron and calcium, but lower in carbohydrate, vitamin $\mathrm{A}$, vitamin $\mathrm{C}$ and zinc than that from edecocoindia. Puddings from $100 \%$ cocoyam of both varieties which recorded higher moisture content will likely be softer than their counterparts with plantain and soybean inclusion. Similarly, ede-ocha puddings will be softer for easier mastication and swallowing by the infants. With enhanced consumption ede-ocha puddings will likely contribute to infants' growth and strong bones by meeting their nutritional requirements than ede-cocoindia.

Besides, this study showed feasibility of compatible economical semi-solid nutritious complementary food from cheap and locally available raw materials from underutilized cocoyam, firm ripe plantain and sprouted soybean pastes. Though complementary puddings from ede-ocha performed better than ede-cocoindia, both are good sources of micronutrients liable to prevent infant malnutrition in developing countries like Nigeria. More so, it will mitigate post-harvest losses, boost cocoyam production and enhance food security.

\section{Conflict of Interest}

The authors declare that there is no conflict of interest. 


\section{Acknowledgement}

The authors are grateful to cocoyam programme of the National Root Crops Research Institute Umudike Abia State Nigeria for supplying the cocoyam used for the study.

\section{References}

[1] UNICEF, Complementary foods and feeding: nutritional companion to breast feeding, 2010. Available: https://www.unicef.org/programme/breastfeeding/food.htm.

[2] C. Agostoni et al, ESPGHAN Committee on Nutrition, J. Pedatr. Gastroentrol. Nutr. 46(1) (2008) 99-110.

[3] E. Oti, E.N.T. Akobundu, Physical, functional and amylography pasting properties of cocoyamsoybean-crayfish flour blends, Nigerian Food J. 25(1) (2007)161-170.

[4] I.N. Okwunodulu, F.U. Okwunodulu, Optimization of tropical storage stability of some micronutrient content of fortified predigested soymilk for complementary feeding, Int. J. Appl. Res. Tech. 5(16) (2016) 94-190.

[5] E. Oti, Development and evaluation of cocoyam, soybean-crayfish based complementary food, PhD Dissertation, Michael Okpara University of Agriculture, Umudike, Nigeria, Department of Food Science and Technology, 2003.

[6] J. Onyeka, Status of cocoyam (Colocasia esculenta and Xanthosoma spp) in West and Central Africa: Production, household importance and the threat from leaf blight. lima (Peru). CGIAR Research Program on Roots, Tubers and Bananas (RTB), 2014. Available: www.rtb.cgiar.org.

[7] P.G. Owusu-Darko et al., Cocoyam (corms and cormels) - An underexploited food and feed resources, J. Agric. Chem. Environ. 3 (2014) 22-29.

[8] L.L. Niba, Processing effects on susceptibility of starch to digestion in some dietary starch sources, Int. J. Food Sci. Nutr. 54 (2003) 97-109.

[9] F. Ucheogu, Processing and quality evaluation of noodles from sweet potato (Ipomoea batatas) starch, Unpublished B.Sc. Project, Department of Food Science and Technology, Abia State University, Uturu, 2000.

[10] E.J. Akpan, I.B. Umoh, Effect of heat and tetracycline treatments on the food quality and acridty factors in cocoyam (Xanthosoma sagittifolium (L) Schott), Pak. J. Nutr. 3(4) (2004) 240-243.

[11] T. Johns, Underutilized species and new challenges in global health, LEISA Magazine. 20(1) (2004).

[12] C.M.F. Mbofung et al., Physicochemical and functional properties of six varieties of Taro (Colocasia esculenta L. Schott) flour, Journal of Food Technology. 4(2) (2006) 135-142.

[13] C.E. Offor et al., Analysis of the anti-nutrients levels in staple food crops in different Local Government Areas of Ebonyi State, Nigeria, Cont. J. Food Sci. Technol. 5(1) (2011) 26-30.

[14] FAO, Roots, tubers, plantains and bananas in human nutrition, Food and Agricultural organization of the United Nations, Rome, 1990.

[15] E.A. Udensi et al., Antinutrient factors of vegetable cowpea (Sesquipedalis) seeds during thermal processing, Pak. J. Nutr. 6 (2007) 194-197.

[16] J.C. Okaka et al., Food and human nutrition: An integrated approach, OJC Academic Publishers, Enugu, 2006, pp. 496-526.

[17] M.A. Odenigbo, Knowledge, attitudes and practices of people with Type 2 diabetes mellitus in a tertiary health care centre, Umuahia, Nig. J. Diabetes Metab. 3 (2012) 187-191. 
[18] T.A. Adeniji et al., Determination of micronutrients and colour variability among new plantain and banana hybrids flours, World J. Chem. 1 (1) (2006) 23-27.

[19] H.D. Zakpan, et al., Production and characterization of flour produced from ripe "apem" plantain (Musa sapientum L. var. paradisiacal; French horn) grown in Ghana, J. Agric. Biotech. Sustainable Dev. 2(6) (2010) 92-99.

[20] K.P. Baiyeri, G.O. Unadike, Ripening stages and days after harvest influenced some biochemical properties of two Nigerian plantains (Musa species AAB) cultivars, Plant Prod. Res. J. 6 (2001) 11-19.

[21] S. Someya et al., Anti-oxidant compounds from plantain, Food Chem. 79 (2002) 351-354.

[22] USDA Nutrient Database. Available at http://en.wikipedia.org/wiki/Cooking_plantain. Retrieved 10 November, 2010.

[23] J.A. Folayan, J.O. Bifarin, Economic analysis of plantain processing industry in Akure South Local Government of Ondo State, J. Agric. Extension Rural Dev. 3(4) (2011) 77-81.

[24] A.S. Amusat, A.O. Ademola, Utilization of soybean in Oniyo community of Oyo state, Nigeria, Global J. Science Frontier Research (D).13(7) (2013).

[25] M.O. Iwe', The Science and Technology of soy bean: Chemistry, Nutrition, Processing and utilization (1st Ed.), Rojoint communication services, Enugu, 2003.

[26] E.F. Fabiyi, Soybean Processing, Utilization and Health Benefits, Pak. J. Nutr. 5(5) (2006) 453457.

[27] M.M.R. Rusydi et al., Nutritional changes in germinated legumes and rice varieties. Intern. Food Research J. 18 (2011) 705-713.

[28] M. Mărton et al., The role of sprouts in human nutrition. A review, Acta Univ. Sapientiae, Alimentaria. 3 (2010) 95.

[29] I.N. Okwunodulu, M.O. Iwe, Micronutrient evaluation of fortified soymilk from sprouted whole soybean for complementary feeding using response surface methodology, J. Mole. Stud. Med. Res. 01(01) (2015) 16-25.

[30] R.E. Sanful, A. Sadik, S. Darko, Nutritional and sensory analysis of soybean and wheat flour composite cake, Pak. J. Nutr. 9 (2010) 794-796.

[31] G.I. Onwuka, Food analysis and Instrumentation. Theory and practices, Naphtali Prints Lagos, Nigeria, 2005. ISBN 978047686.

[32] S.C. James, Analytical chemistry of food, Chapman and Hill printers, London, 1995.

[33] A.O.A.C. (1995). Official Methods of Analysis. $15^{\text {th }}$ Edition. Association of Official Analytical Chemists. Washington DC.

[34] D.E. Okwu, C. Josiah, Evaluation of chemical composition of two Nigerian medicinal plants, African Journal of Biotechnology. 5(4) (2006) 357-361.

[35] A.K. Dixit et al., Soybean consistuent and their functional benefits, in: V.K. Tiwari, B.B. Mishra (Eds.), Opportunity, challenge and scope of natural products in medicinal chemistry, Research signpost Publication, Kerala, India, 2011, pp. 367-383.

[36] C. Byid-Bredbenner et al., Wardlaw's Perspectives in Nutrition, $9^{\text {th }}$ Edition, McGraw-Hill, New York, 2013.

[37] A.C. Uwaegbute, Adequate Infant Feeding: Bed Rock for National Development, Poverty Alleviation and Empowerment, Sixth Inaugural Lecture at Michael Okpara University of Agriculture, Umudike, 2008, 1-47. 
[38] SFGATE (2017). How much Protein should a Child Have? Available: http://healthyeating.sfgate.com/much-protein-should-child-have-422.

[39] FAO/WHO (1998). Preparation and use of Food-Based Dietary Guidelines. Report of a Joint FAO/WHO Consultation. WHO Technical Report series 880. Geneva. 15.

[40] D. Barclay, Multiple Fortification of Beverages, 2011. Available: http://unu.edu/unupress/food/v192e/ch13.htm.

[41] E.A. Thiers, Water and Nutrition, 2009. Published by Lenntech Water Treatment and Purification Holding B. U. http:/www.lenntech.com/about lenntech.htm.

[42] S. Fallon, M.G. Enig, Nourishing Tradition, in: The cookbook that challenges Politically Correct Nutrition and the Diet Dictocrates, New Trends Publishing Inc., 2007.

[43] L. Davidson et al., Sodium Iron EDTA (NaFEe (111) EDTA) as a Food Fortificant:Crythrocyle Incorporation of Iron and Apparent Absorption of Zinc, Copper, Calcium and Magnesium, from a Complementary Food based on Wheat and Soy in Healthy Infants, Am. J. of Clinical Nutri. 8(1) (2005) 104-109.

[44] WhereinCity Medical (WM) (2009). Calcium. Wherencity Medical http://www.wherencity.com/medical/minerals/cdcium.php.

[45] I. Olayiwola et al., Chemical, mineral composition, and sensory acceptability of cocoyam-based recipes enriched with cowpea flour, Food Science and Nutrition. 1(3) (2013) 228-234.

[46] SFGATE (2017), Normal Fiber Intake for Children. Haelthyeating.sfgate.com/normal-fiberintake-children-4548-html.

[47] SFGATE (2017). Carbohydrate needs in Children. Available: $\mathrm{http} / /$ healthyeating.sfgate.com/carbohydrate- needs-children-8050.html.

[48] R.L. Duyff, American Dietetic Association. Complete Food and Nutrition Guide, Revised and Updated $4^{\text {th }}$ Edition, Houghton Mifflin Harcourt Publishers, New York, 2006, Pp. 315.

[49] Natural Food Hub [NFH] (2001). Natural Food-- Fruit Vitamin C Content. Available: http://www.naturalhub.com/natural_food_guide_fruit_vitamin_c.htm

[50] MedicineNet (MN) (2011), Definition of Ascorbic Acid. Available: https://www.medicinenet.com/script/main/art.asp?articlekey=12536.

[51] Wikipedia, (2011). Ascorbic Acid. Available: http://en.wikipedia.org/wiki/Ascobicacid.

[52] Office of Dietary Supplementary (ODS) (2007), Dietary Supplements Fact Sheat: Iron Office of Dietary Supplements National Institute for health.

[53] P. Das, N. Raghuramulu, K.C. Rao, Determination of in vitro availability of iron from common foods, J. Human Ecol. 18(1) (2005) 13-20.

[54] G.M. Wardlaw, A.M. Smith, Contemporary Nutrition, Eighth Edition, McGraw-Hill Publishers, New York, 2011, Pp. 89.

[55] B.O. Green, Taxonomic and nutritional analysis of certain tuber crops in the Niger Delta of Nigeria, Afr. J. Environ. Studies. 4 (2003) 120-122.

[56] Better Health Channel (B.H.C) (2009), Calcium-Factsheet. Available: www.better health.vic.gov.au. 